\title{
Classical Elements of Nature in Galway Kinnell's The Book of Nightmares
}

\author{
Elizabeth Quirós-García * \\ https://orcid.org/0000-0003-0149-1844
}

Recibido: 26 de febrero de 2020 • Aceptado: 24 de abril de 2020

\begin{abstract}
The aim of this study is to analyze Kinnell's The Book of Nightmares from an archetypal and mythological approach. While there have been different approaches to reading Kinnell's book-length poem, their primary concern has been Kinnell's work in relation to other poets of his generation rather than the analysis of the booklength poem as a unity in which archetypes and myth intersect, with a central focus that is: the classical elements (water, fire, air, and earth), as fundamental elements for the resolution of the binary oppositions life and death in the hero's quest. Therefore, for the purpose of this study, the Jungian archetypal approach will be assumed as well as Campbell's mythical focus, considering that these perspectives are still a valuable means for the analysis of literary texts.
\end{abstract}

Key words: Poetry, US literature, English, archetype, myth.

\footnotetext{
* Magister Literatum, literatura inglesa, de la Universidad de Costa Rica (UCR), Costa Rica. Bachiller en inglés de la UCR. Maestría en Administración de Negocios con énfasis en Gerencia de la Universidad Latina, de Costa Rica. Magister en Educación de la Universidad Americana (UAM), de Costa Rica. Profesora e investigadora de la Escuela de Lenguas Modernas, Facultad de Letras de la UCR. Correo: elizabeth.quiros@ucr.ac.cr
} 


\section{Los elementos clásicos de la naturaleza en El libro de las pesadillas de Galway}

Kinnell

\section{Resumen}

El objetivo de este estudio es analizar El libro de las pesadillas del poeta Galway Kinnell desde un enfoque arquetípico y mitológico. Si bien, el libro ha sido estudiado bajo diferentes enfoques, especialmente la del autor y su generación literaria, el análisis del poemario como unidad, en la que los arquetipos y los mitos intersecan, es obligatorio. Fundamentalmente si se consideran los cuatro elementos clásicos de la naturaleza (agua, fuego, aire y tierra) y su simbología en el poema, para la exitosa resolución de los opuestos binarios vida y muerte en el viaje del yo lírico. Consecuentemente, para el propósito de este estudio se asumirá un enfoque arquetípico Jungiano y el mitológico de Campbell, con el interés de demostrar que estas perspectivas siguen siendo valiosas para el análisis de textos literarios.

Palabras clave: Poesía, literatura estadounidense, inglés, arquetipo, mito.

\section{Éléments classiques de la nature dans Le livre des cauchemars de Galway Kinnell.}

\section{Résumé}

L'objectif cette étude est d'analyser Le livre des cauchemars du poète Galway Kinnell dès l'approche archétype et mythologique. Bien que le livre ait été étudié sous diverses approches, notamment celle de l'auteur et son genre littéraire, l'analyse du recueil de poèmes, comme unité dans laquelle les archétypes et les mythes s'entrecroisent, devient obligatoire, principalement, si l'on considère les quatre éléments classiques de la nature (l'eau, le feu, l'air et la terre) et leur symbologie dans le poème. C'est ainsi que d'après le but de cette étude, on a assumé l'approche archétype Jungienne et l'approche mythologique de Campbell en visant à démontrer que ces perspectives continuent à être utiles pour l'analyse des textes littéraires.

Mots-clés: Poésie, littérature étatsunienne, anglais, archétype, mythe. 


\section{Introduction}

Galway Kinnell was born on February 1, 1927, in the United States of America, Providence, Rhode Island and died on October 28, 2014 in Vermont. His parents were both immigrants to the United States from the United Kingdom. From 1933 to 1943, he attended public school in Rhode Island, until he received a scholarship to attend Wilbraham Academy in Massachusetts for his senior year. In 1948, as Calhoun ${ }^{1}$ affirms, he graduated from Princeton where «he was a brilliant student, graduating summa cum laude» in 1949, he received an M.A. in English in the University of Rochester. From 1951-55 he lived in Chicago working as professor at the University of Chicago. Kinnell is considered one of the major North American authors of the XX century and is depicted as «one of our most accomplished poets, a fact that is one of the best kept secrets among contemporary writers, known only to a select group of poets who recognize his skills» ${ }^{2}$.

Mills $^{3}$ states that a significant number of Kinnell's poetic work takes into consideration the natural world that offers him infinite possibilities for his «imaginative meditation». These natural images range from creeks to more primitive and basic needs in life like food and shelter. It is through this entrance to the natural world that the critic and reader can also encounter a threshold «into a primitive state of identification with the nonhuman $»^{4}$. As Aseel Abdul-Lateef Taha ${ }^{5}$ declares, in "The allegorical use of rituals of hunting in Galway Kinnell's "The bear"». It seems that in his poetry, the acknowledgement of humankind's primitive and archaic drives may lead to a moment of liberation and harmony with life itself.

In this poet's work, the primeval is portrayed as essential to human understanding of life; for example, it is within the primitive that Kinnell expands this experience with the symbolic constituent of fire, as a basic element in life cycles of constant transformation in the infinite process of death and resurrection. Howard ${ }^{6}$ asserts that there is agony in knowledge and that in order for life to exist, life itself must be consumed, «must be reduced to ash in order to be redeemed - gives Kinnell's poetry its astonishing resonance, the accents of a conflict beyond wisdom as it is beyond pity». It is this paradox that makes Kinnell's poetry so attractive, just as humankind is permeated with unresolved polarities. Moreover, Williamson ${ }^{7}$ states that poets «as few others, must live close to the world that primitive men are in: the world, in its nakedness, which is fundamental for all of us - birth, love, death, the seer fact of being alive». And this is what Kinnell does in his work, that is, he takes the readers back to their most rudimentary beginning to give meaning to life.

\footnotetext{
${ }^{1}$ Richard Calhoun, Myths to live by (New York, Anchor Books, 1992).

${ }^{2}$ Richard Calhoun, Myths... ix.

${ }^{3}$ Ralph J. Jr. Mills, «A reading of Galway Kinnell». The Iowa Review 1, n 1, (1970a) 67.

${ }^{4}$ Ralph J. Jr. Mills, «A reading of... 54.

5 Aseel Abdul Lateef Taha, «The Allegorical Use of the Rituals of Hunting in Galway Kinnell's “The Bear"», Journal of the College of Languages, n. ${ }^{\circ} 28$ (2018).

${ }^{6}$ Richard Howard, Alone with America: Essays on the art of poetry in the United States (New York: Atheneum, 1980), 260.

${ }^{7}$ Harold Bloom, Contemporary Poets. Ed. (New York: Infobase Publishing, 2010), 170.

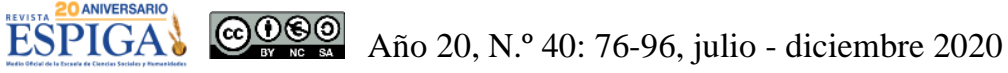


On his part, Mills ${ }^{8}$ affirms that in his poetry, Kinnell faces «himself and the conditions of the world simultaneously, without mediation or disguise. It should be said, however, that Kinnell employs other means than nature for cutting to the bone of existence, though intimate acquaintance with other living creatures and with the earth is of primary importance to his work». Definitely, in his poetry, there is a robust connection with nature that allows the reader to appreciate the natural world: earth, trees, flowers, animals, and even rocks; however, his work is not subjugated to these. Moreover, Atlas ${ }^{9}$ asseverates that Kinnell is so «close to his subject, the natural world in all its tyranny and splendor, that his sympathies are readily translated into the richness of cadence and language that poetry should always have». It is Kinnell transmuting ordinary experiences of babysitting, cooking, traveling and the sort into extraordinary every day happenings that become a source of inspiration and revelation through his poetic work.

\section{Methodology}

Considering the reading of The Book of Nightmares through an archetypical approach, myth is essential. Thus, from the many differing theoretical approaches to myth and archetypes, those of Carl Gustav Jung, and Joseph Campbell are favorable for this particular study since these scholars work with the mythical and archetypal position. Consequently, these theoretical frames will offer the approach for reading the book-length poem aiming to converge on the relation between the content and context of the text with the theories chosen for the analysis. Accordingly, the theories of Jung and Campbell will be interrelated in that they develop a critical basis for discussing the concept of the myth archetype.

In the XIX century, the scholar J.G. Frazer published The Golden Bough, book in which he studied religious rituals and myth from different cultures around the world. According to Nandi ${ }^{10}$ and based on his analysis of archetypal patterns «Frazer argues that the death-rebirth myth is present in almost all cultural mythologies and is acted out in terms of growing seasons and vegetation. The death-rebirth myth is symbolized by the death (i.e. final harvest) and rebirth (i.e. spring) of the god of vegetation». Consequently, it can be asserted that Frazer's approach to mythology is based on the concrete elements of the physical world and his central motif is the archetype of resurrection, specifically the myths describing the assassination of the divine sovereign while Jungian criticism on its part aims at understanding the literary work and its connection with the collective unconscious.

Taking into consideration these common elements, Jung worked and developed the concept of archetypes. According to Maduro \& Wheelwright ${ }^{11}$, «Jungian theory holds that the mind is not a tabula rasa at birth but that there is an archetypal ground plan built into the structure of the human brain». Hence, humankind shares immaterial content in their psyche and the primeval representations that Jung sees that repeat are what he addresses as archetypes. According to Jung, there are

\footnotetext{
${ }^{8}$ Ralph, J. Jr. Mills, «A reading of...», 68.

${ }^{9}$ Howard Nelson, On the Poetry of Galway Kinnell (Michigan: The University of Michigan Press. 1987), 97.

${ }^{10}$ Nandi, Rinku. «Archetypal approach to Eliot's "The Wasteland”». An Interdisciplinary Journal of Literary Studies 1, n. ${ }^{\circ} 1$ (2016): 58.

${ }^{11}$ Sugg, Richard, ed. Jungian Literary Criticism. Evanston (Illinois: Northwestern University Press, 1992), 182.
} 
repetitive patterns that stem from structures in the human mind that are considered common to people from all around the world; these patterns are motifs, themes, narrative organization of the text, characters, and images that are found when analyzing a work of literature under the lens of archetypal and mythical criticism. Consequently, much of the aim of this research will be to look for an understanding of these universal patterns in Kinnell's book-length poem through the use of classical elements in nature.

Furthermore, in Jungian psychology, one person's psyche can be seen as their total personality and it may circumscribe to a person's behavior, thoughts, feelings, and emotions. Consequently, if the mind is in control of who a person is, Jung's outmost concerns was to find paths to understand it. Hence, he divided the mind into three main realms that are the consciousness, the persona unconsciousness, and the collective unconscious; all of them in a dynamic interplay that will lead into potential growth and change: the individuation process. Jung's invention of the collective unconscious was stimulated by far-reaching analysis of the unconscious material of his patients such as their dreams and fantasies as well as his studies of comparative religions and mythology. He found out mysterious similarities in his patients' dreams but there were also uncanny similarities in major mythological motifs and religious symbols around the world. Hence, in the first part of the XX century, Jung ${ }^{12}$ did an extensive process of self-analysis defined as "confrontation with the unconscious» and it is in this period that he defined and described the structures of his theory on archetypes and the collective unconscious, among others. According to Jung ${ }^{13}$, in his work Archetypes and the collective unconscious, from the unconscious realm

[...] there emanate determining influences which, independently of tradition, guarantee in every single individual a similarity and even a sameness of experience, and also of the way it is represented imaginatively. One of the main proofs of this is the almost universal parallelism between mythological motifs, which on account of their quality as primordial images, I have called archetypes.

Consequently, the concept of «archetype» is distinctive of Jung's terminology. As his research continued, he realized that many symbols form part of mythology, stories, fairy tales, and all kinds of artistic and creative human productions which he unified in the concept of the collective unconscious. In the light of this reading, all human beings have access to an infinite experiences and knowledge of the human condition that lies below the personal unconscious. Samuels ${ }^{14}$, in his book Jung and the Post-Jungians, sustains that

Jung begins from the human interaction in analysis or from observation of life, develops a theory which is then illustrated by comparative material or

\footnotetext{
${ }^{12}$ Carl G. Jung, Memories, Dreams, Reflections (New York: Pantheon, 1961), 170-199.

${ }^{13}$ Carl G. Jung, The Archetypes and the Collective Unconscious. (London: Routledge \& Kegan Paul, 1959), 58.

14 Andrew Samuels, Jung and the Post-Jungians (London and New York: Routledge \& Kegan Paul, 1985), 5. 
further observation. Only then could the mass of imagery and data from many sources be organised. The organisation itself then helps to understand one aspect or other of human behavior. Thus, the process is circular: human material - theory - illustration - application to human behavior.

Accordingly, Jung's theory develops into a continuum in which human experience becomes the source of knowledge that is then clarified and contrasted to other resources and as a result, knowledge about human behavior is attained. Furthermore, in Man and his symbols, Jung ${ }^{15}$ announces that

Man uses the spoken or written word to express the meaning of what he wants to convey. His language is full of symbols, but he also often employs signs or images that are not strictly descriptive... What we call a symbol is a term, a name, or even a picture that may be familiar in daily life, yet that possesses specific connotations in addition to its conventional and obvious meaning. It implies something vague, unknown, or hidden from us.

Therefore, the words used by humankind are not as simple as a dictionary entry; on the contrary, words are filled with meaning, within a connotative realm, based on the person's usage of word(s). Hence, even when most people relate to the denotative meaning of a word, the latter may have a different representation in the psyche of the person that is using it. He goes further affirming that due to the fact that there are incalculable «things beyond the range of human understanding, we constantly use symbolic terms to represent concepts that we cannot define or fully comprehend... Man also produces symbols unconsciously and spontaneously, in the form of dreams ${ }^{16}$. Thus, the realm of meaning, through which people try to understand the inner and outer self and the world around, goes beyond what can be explained logically.

Therefore, it is fundamental to consider that myths must be approached symbolically as to reveal «truths» about the humankind psychic existence and that myths exist today; or as Barthes ${ }^{17}$ discusses that

There are no eternal ones; for it is human history which converts reality into speech, and it alone rules the life and death of mythical language. Ancient or not, mythology can only have a historical foundation, for myth is a type of speech chosen by history: it cannot possibly evolve from the 'nature' of things.

Consequently, myth can be defined neither by its object nor by its material, for any material can arbitrarily be endowed with meaning: for instance, the arrow which is brought in order to signify a challenge is also a kind of speech. Besides defining the

\footnotetext{
${ }^{15}$ Carl G. Jung, Man and his Symbols (New York: Dell Publishing Co., Inc, 1964), 3.

${ }^{16}$ Carl G. Jung, Man..., 4.

${ }^{17}$ Roland Barthes, Mythologies (New York: Hill and Wang, 1999), 110. 
term myth, it is also critical to state its purpose; consequently, Campbell ${ }^{18}$ affirms that «it has always been the prime function of mythology and rite to supply the symbols that carry the human spirit forward, in counteraction to those constant human fantasies that tend to tie it back». As he asserts, humankind requires rituals and representations to function in society. Thus, even when people might not be aware of myth and rituals as part of their lives, he declares that they do participate in rituals through simple and everyday acts like eating. Campbell ${ }^{19}$ enumerates four main functions of mythology that are:

- 1st function: «Awakening in the individual a sense of awe and mystery and gratitude for the ultimate mystery of being.»

- 2nd function: «Serves to present a universe within which the mystery as understood will be present, so that everywhere you look it is, as it were, a holy picture, opening up in back to the great mystery.»

- 3rd function: «Gives you laws for living within your own society.»

- 4th function: «Gives a way to connect the inner psychological world to the external world of phenomena.»

It must be recalled that humankind has been bestowed upon former knowledge and wisdom to understand the world not only denotatively but also connotatively, and the access to this information can be done through symbols and archetypes; it is this undertaking the one that will be seized in the study of this book-length poem.

\section{Classical elements of nature in The book of nightmares}

The idea of understanding how the Earth and humanity were created is a primeval curiosity in individuals' minds. Hence, thousands of years ago, ancient scholars believed that there were four elements that constituted, in different combinations, what is known by humankind. These four elements are earth, air, fire, and water and they represent different characteristics that can be seen in what surrounds human civilization. Earth is the element that is the weightiest and it is commonly associated with fertility, stability and prosperity. According to Ferber ${ }^{20}$, «late ancient sources, the Orphics praised Physis as the mother of all, all-wise, all-ruling, and immortal; if so, that was the first instance of «Mother Nature», but the personification was not sustained. The more ancient myths about Gaia (Earth) must also have encouraged this personification». Air, on its part, is lighter and it is related to creativity and the intellect ${ }^{21}$. Fire is characterized by being the lightest of the four elements besides

\footnotetext{
${ }^{18}$ Joseph Campbell, Pathways to Bliss (California: New World Library, 2004a), 7.

${ }^{19}$ Joseph Campbell, Pathways..., 104-108.

${ }^{20}$ Michael Ferber, A Dictionary of Literary Symbols (Cambridge: Cambridge University Press, 1999), 133.

${ }^{21}$ According to Cirlot (1962), «Of the four Elements, air and fire are regarded as active and male; water and earth as passive and female. In some elemental cosmogonies, fire is given pride of place and considered the origin of all things, but the more general belief is that air is the primary element. Compression or concentration of air creates heat or fire, from which all forms of life are then derived. Air is essentially related to three sets of ideas: the creative breath of life, and, hence, speech; the stormy wind, connected in many mythologies with the idea of creation; and, finally, space as a medium for movement and for the emergence of lifeprocesses. Light, flight, lightness, as well as scent and smell, are all related to the general symbolism of air (p. 3). Gaston Bachelard says that for one of its eminent worshippers,
} 
being connected to characteristics of transformation and strength. As Cirlot ${ }^{22}$ discusses:

For most primitives, fire was a demiurge emanating from the sun, whose earthly representative it was; hence it is related on the one hand with the ray of light and the lightning, and, on the other, with gold. Frazer lists many rites in which torches, bonfires, burning embers and even ashes are considered capable of stimulating the growth of the cornfields and the wellbeing of man and of animals.

Finally, water is conventionally linked to symbolic features of divination, intuition, and change. For $\mathrm{Cirlot}^{23}$, water «symbolize[s] the universal congress of potentialities, the fons et origo, which precedes all form and all creation. Immersion in water signifies a return to the preformal state, with a sense of death and annihilation on the one hand, but of rebirth and regeneration on the other, since immersion intensifies the life-force».

It was believed that these four elements of nature could combine harmoniously to perfect the philosopher's stone: being this stone a reflection of the perfect self. Moreover, something worth noticing in the use of these elements in The Book of Nightmares and its analysis considering a Jungian approach, is that they are also present in the mandala. In relation to this symbolic representation and according to Jung $^{24}$ :

Among the mythological representations of the Self one finds much emphasis on the four corners of the world, and in many pictures the Great Man is represented in the center of a circle divided into four. Jung used the Hindu word mandala (magic circle) to designate a structure of this order, which is a symbolic representation of the "nuclear atom» of the human psyche whose essence we do not know. In this connection it is interesting that a Naskapi hunter pictorially represented his Great Man not as a human being but as a mandala.

In this «magic circle», surrounded by the four elements, the self is found through the reunion of the most basic dreams and visions fundamental to humankind; therefore, the individuation process searches for completeness. Likewise, in the book-length

Nietzsche, air was a kind of higher, subtler matter, the very stuff of human freedom. And he adds that the distinguishing characteristic of aerial nature is that it is based on the dynamics of dematerialization. Thoughts, feelings and memories concerning heat and cold, dryness and humidity and, in general, all aspects of climate and atmosphere, are also closely related to the concept of air. According to Nietzsche, air should be cold and aggressive like the air of mountain tops. Bachelard relates scent to memory, and by way of example points to Shelley's characteristic lingering over reminiscences of smell» (p. 6).

22 Juan E. Cirlot, A Dictionary of Symbols (Translated by Jack Sage. London: Routledge, 1962), 106.

${ }^{23}$ Juan E. Cirlot, A Dictionary..., 365.

${ }^{24}$ Carl G. Jung, Man..., 210.

ESPIGAd (c) (1) (2) Año 20, N. ${ }^{\circ}$ 40: 76-96, julio - diciembre 2020 
poem, the persona acknowledges the purpose of his journey through the encounter with these four elements through the completion of the cycle (roundness as the mandala). When the quester commenced his journey in the pursuit for inner realization, following indications from the outer world and a seemingly more objective reality, he is able to allow his own self to emerge, acquiring what he lacked and that is translated into the understanding of the binary oppositions of life and death. From the four elements, the first one to be discussed is fire that besides bringing pain can also illuminate; as the discussion continues, water, air, and earth will be analyzed in relation to the poetic images depicted in Kinnell's The Book of Nightmares.

\section{Fire}

As an element of the quartet being discussed, the element of fire is central to understand the persona's journey of self-discovery in the book-length poem. Fire has been ascribed a positive connotation when it is found in the tree of knowledge, the tongues of fire mentioned in the Bible, or the visit and inspiration of the Holy Spirit at the Christian Pentecost; nevertheless, this element is also granted less positive symbolic meanings when found in the fires of Hell or the destruction of libraries or entire civilizations. But besides these fundamental characteristics of fire, there is one that makes it essential when understanding the persona's journey and his learning progression: fire is the only element that humanity can produce; consequently, it may symbolize the similarity between humankind and a supreme being. Biedermann ${ }^{25}$, when analyzing the element of fire, acknowledges that even when fire may present seemingly opposing interpretations,

Still, the notion of fire as «the flame of life» dominates, especially with its progressive taming over the course of civilization: this is indicated by our preservation of ancient customs like torchlight processions and lighting midsummer's - night fires on mountaintops - or eating by candlelight in the era of electrification.

As this author discusses, fire will also entail positive moments in the quester's journey. As the hero starts his journey, fire is made visible, when he «light[s] a small fire in the rain ${ }^{26}$ and this image, accompanies him throughout his quest as he keeps moving and «sit[s] a moment / by the fire, in the rain» ${ }^{27}$. As the quester moves forward, he will understand that this simultaneity of the rain in the fire will make both elements morph but not extinguish one another. He sees the fire and feels its warmth as he commences his path; moreover, as he reaches the culminating phase of the last stage, he encounters the bonfire that «goes on flaring in the rain» one more time; and this glare

No matter, now, who it was built for,

${ }^{25}$ Hans Biedermann, Dictionary of symbolism (Translated by James. Hulbert. New York: Facts on File. 1992), 130.

${ }^{26}$ Kinnell, The Book of Nightmares.

${ }^{27}$ Kinnell, The Book of Nightmares.

ESPIGA' @)(1) (1) Año 20, N. ${ }^{\circ}$ 40: 76-96, julio - diciembre 2020 
it keeps its flames,
it warms
everyone who might wander into its radiance,
a tree, a lost animal, the stones,
because in the dying world it was set burning ${ }^{28}$.

This last verse symbolizes the hope for new life as with the image of a phoenix that is purified to death by the fire of the flame and rises as new from the ashes. Even when this emblematic element may seem contradictory, it depicts the understanding of the life-death continuum for in destruction renewal is found. Furthermore, another essential characteristic of the persona's maturity is his understanding that the flame that offers its warmth is there for all those that need it; and in some cases as Jung ${ }^{29}$ asseverates within the person for «(...) the soul is a fire or flame, because warmth is likewise a sign of life». Kinnell, in his poetry, as Jung, in his studies of the psyche, offer humanity the opportunity of comprehending the existence and relevance of that inner life that everyone owns, but may not know, in a journey of self-discovery (the unconscious), through the resolution of the binary oppositions life-death.

\section{Water}

As fire, water is another element that guides the hero in his quest as it is part of different myths being an elemental fluid from which life emanates; nevertheless, as fire, water may depict positive as well as negative symbolic meanings. The ambivalence of the element can be identified in myths that display closing cycles of creation, like the Christian Flood, or the opportunity of growth that rain represents for the crops and produce. Moreover, it can guide individuals' steps when looking for meaning or knowledge; for example, the river that needs to be sailed to reach Hades, or any other body of waters that guides the quester.

A constant metaphor of life as well as of death in the text is the imagery of water. This natural element is present in two forms: the rain and the river. The symbolic value of the rain has been established as a negative and ominous element, but also as a symbol of life and rebirth. As the poem starts, the quester is faced with a soft rain that will accompany him and that will go full circle in the last poem. Likewise, the river is another essential emblematic element in the poem for it signals different stages in the development of the hero: his descend into «hell», his sadness as he discovers that the «Juniata» and its surroundings have been damaged, the happiness he projects on the future of his daughter as he envisions her next to the banks of the Seine river in France, and in the last section of the poem when he completes his journey. This subsection will discuss both natural elements and their possible interpretation.

In The Book of Nightmares, the first image in the poem is a rainy place where the persona «light[s] / a small fire», image that may look paradoxical but within the dichotomy life-death answers the riddle for one is part of the other, especially when

${ }^{28}$ Kinnell, The Book of Nightmares.

${ }^{29}$ Meredith Sabini, ed.C.G. The Earth has a Soul: Jung on Nature, Technology \& Modern Life. (1st ed. California: North Atlantic Books, 2001), 92.

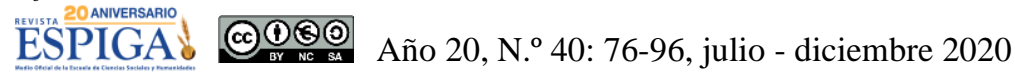


The raindrops trying

to put the fire out

fall into it and are

changed: the oath broken,

the oath sworn between earth and water, flesh and spirit, broken,

to be sworn again,

over and over, in the clouds, and to be broken again,

over and over, on earth ${ }^{30}$.

The rain falls to put the fire out but, when it falls into the fire, it changes and the promise breaks to «be sworn again» like «[t]he still undanced cadence of vanishing» ${ }^{31}$; this promise reflects a renewal in which death materializes not to complete a cycle but to regenerate it. As with other symbolic elements in the poem, this apparently broken oath water/rain emerges again eternally in the ceaseless lifedeath continuum. Moreover, this image of the rain in communion with the earth symbolizes the unity of the mortal and the eternal realms: water and earth; hence, the life-death dichotomy is resolved again as it did with the element of fire. The existence of this dichotomy is not foreign for humankind, as $\mathrm{Paz}^{32}$ announces

Cada pueblo sostiene un diálogo con un interlocutor invisible que es, simultáneamente, el mismo y el otro, su doble... La dualidad no es algo pegado, postizo o exterior; es nuestra realidad constitutiva: sin otredad no hay unidad. Y más: la otredad es la manifestación de la unidad, la manera en que esta se despliega...La otredad nos constituye . $^{33}$.

As this scholar declares, when a person realizes that there is always an «opposite», even within, as a duality that resides in him/herself, his/her experience of life will be more fulfilling, for without one or the other there will be no unity, no individuation process. Likewise, life and death become elements of the same unity; in the poem being discussed, eternity and ephemerality become a unity when the zero, representing eternity, and number one, symbolizing mortality, promenade together:

... It is right

${ }^{30}$ Galway Kinnell, The Book of Nightmares (Boston: Houghton Mifflin Company 1971a), 4.

${ }^{31}$ Galway Kinnell, The Book of..., 52.

32 Octavio Paz, El Laberinto de la Soledad (Madrid: Ediciones Cátedra, 1995), 390-391.

33 «Each civilization maintains a dialogue with an invisible interlocutor that is at the same time himself and the other, its double. This duality is not something bonded, foreign or external; it is our constitutive reality: without otherness there is no unity. Besides, otherness is the manifestation of the unity, the way in which it unfolds ... Otherness makes us who we are» (my translation). 
at the last, that one

and zero

walk off together,

walk off the end of these pages together,

one creature

walking away side by side with the emptiness ${ }^{34}$.

This moment of unity between life and death are subsequent to the unity of mortality and immortality when the persona sees «[o]n the river the world floats by holding one corpse ${ }^{35}$; the waters of the river symbolizing eternity are presented to the hero as being tied to death, through the corpse, element that keeps the world and its inhabitants «afloat». Through the use of the element of water and its interaction with other natural components, The Book of Nightmares leads the hero to the understanding of the binary oppositions of life and death, emancipating him from previous attachments to the traditional concept of «living». Likewise, the element of the air plays an essential role in the resolution of the aforementioned opposition; this third element has been characterized by its incorporeal form and its capacity to offer the breath of life. Furthermore, it symbolizes creativity and communication; however, as the previous elements discussed, it can also display features of destruction.

\section{Air}

This third element to be discussed is featured as a masculine element that represents intelligence and beginnings. This fundamental archetypical pattern is experienced by the hero throughout his journey so that he can understand the life-death polarity. According to Jung ${ }^{36}$, in the wind, «the spirit is always an active, winged, swift moving being that vivifies and stimulates», phenomenon that the persona lives when he witnesses how a promise between elements is eternally made on it: «over and over, in the clouds ${ }^{37}$; moreover, the hero then moves forward on earth to find the bear «(...) nodding from side / to side. He sniffs / the blossom-smells, the rained earth ${ }^{38}$. After breathing air, the creature smells how the air becomes one with the water, the rain, and the earth; these three elements are made visible through their unification. Additionally, the air retakes its position as a life giver when baby Maud is born and

(...)

they hang her up

by the feet, she sucks

air, screams

${ }^{34}$ Galway Kinnell, The Book of..., 73.

${ }^{35}$ Galway Kinnell, The Book of..., 73.

${ }^{36}$ Carl G. Jung, The Archetypes..., 210.

${ }^{37}$ Galway Kinnel, The Book of..., 4.

${ }^{38}$ Galway Kinnel, The Book of..., 4. 
her first song - and turns rose

the slow

beating, featherless arms

already clutching at the emptiness ${ }^{39}$.

The air offers the baby the chance of a new beginning out of the darkness of the life experienced in the womb for, as she breathes her first breath, she cries. However, her «song» is not a melody but a «scream» that lets others, and herself, comprehend that she has taken her next step in the life-death cycle. Step that may not be comprehended at first but until individuals undergo change, in its broadest meaning. Furthermore, the last verse in which the persona describes the baby holding into the abyss, the air that is intangible, is resolved at the end of the poem when the persona with «this free floating of one / opening his arms into the attitude / of flight, as he obeys the necessity and falls $\ldots\rangle^{40}$. When accepting the existence of this contradiction, giving yourself to the void to live, the persona is ready to soar beyond what may be experienced in the ephemeral reality of humankind.

Likewise, as the persona persists in his journey, the element of air is found one more time to remind him that when moving forward, the pursuit of knowledge some concepts and judgements vanish as

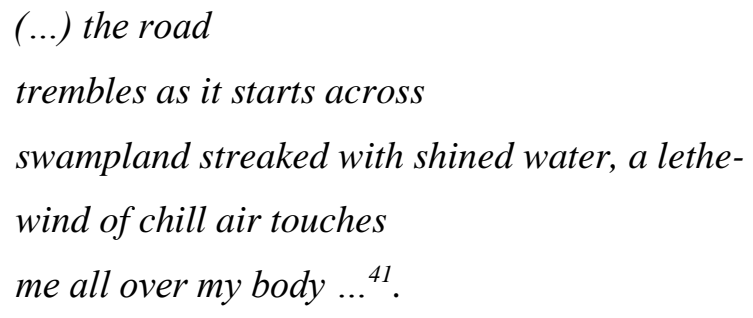

His passage is not easy and so he makes sure the observer knows this detail for, as he walks the path, it shakes making his steps hesitant; moreover, the trail takes him to a bayou guiding him to a potential «Hades». This reflection of the verses is extrapolated from the reference to «Lethe», the river in the Greek underworld that makes its drinkers forget their past; similarly, the wind, as the Greek god Hermes that serves as messenger of the gods, supplies this forget-the-past moment in an embrace that he does not see but feels. The element air then becomes the means through which the persona reaches a state necessary to comprehend what is to come in his journey.

\section{Earth}

The wind is an element that propitiates moments of beginning in the quest of the hero; similarly, the element of earth, a feminine principle, is revealed in The Book of Nightmares. Earth provides humanity the opportunity of a place to dwell and to be

${ }^{39}$ Galway Kinnel, The Book of..., 6-7.

${ }^{40}$ Galway Kinnel, The Book of..., 75.

${ }^{41}$ Galway Kinnel, The Book of..., 21. 
protected; thus, this nurturing element allows the hero to complete his cycle of discovering who he is. As Jung ${ }^{42}$, declares: «[n]atural life is the nourishing soil of the soul. Anyone who fails to go along with life remains suspended, stiff and rigid in midair» characteristic to the persona; so is the encounter of this fourth element for the hero:

\author{
A black bear sits alone \\ in the twilight, nodding from side \\ to side, turning slowly around and around \\ on himself, scuffing the four-footed \\ circle into the earth ${ }^{43}$.
}

In this moment, the bear materializes (being this a special time of the day «twilight» when the day meets the night); moreover, it moves from one side to the other achieving its personal mandala when rotating and drawing a «four-footed» circle on earth that represents the reunion of the four elements: water, fire, air, and earth. This last element provides the unifying constituent for the quester to acquire the knowledge needed to complete this journey and fulfill his goal of reintegration with society. The hero's isolation throughout the journey harmonizes with Paz's ${ }^{44}$ declarations when he affirms that

El doble significado de la soledad - ruptura con un mundo y tentativa por crear otro - se manifiesta en nuestra concepción de héroes, santos y redentores... La soledad es ruptura con un mundo caduco y preparación para el regreso de la lucha final... Y todos, en nuestra propia vida y dentro de las limitaciones de nuestra pequeñez, también hemos vivido en soledad y apartamiento, para purificarnos y luego regresar entre los nuestros ${ }^{45}$.

This journey has asked from the hero strenuous and demanding requests to be able to return to his kind, humanity. Moreover, his effort for finding enlightenment through the encounter with natural elements to understand the death-life binary opposition is closing its cycle. Likewise, the consequence of acquiring this realization for his own life is reaching completeness when considering the element of earth, a feminine principle that guides him into grounding this knowledge.

\footnotetext{
${ }^{42}$ Meredith Sabini, The Earth..., 67.

${ }^{43}$ Galway Kinnel, The Book of..., 71.

${ }^{44}$ Octavio Paz, El Laberinto..., 352-353.

45 «The double meaning of solitude - a rupture with one world and the attempt to create another - is manifested in our conception of heroes, saints, and redeemers... Solitude is the rupture with a caducous world and the preparation for the return and final contestation... Besides, in our own life experience and within the limitations of our own smallness, we have all lived in solitude and withdrawal, so that we can be purified and then be able to go back to our kind» (my translation).
} 
In fact, earth is a symbolic element that is usually associated with being connected to the soil and consequently to nature; furthermore, it is related to the cycles of life for without the soil, there would be no crops, and without these there would be no nourishment for humankind; without the soil, there would be no trees, and without trees there would be no water and no fire. Most of the creatures in the poem live on earth or on elements rooted to earth; the rocks come from earth and the fire is set burning on it; it could be asserted that earth symbolizes humankind's connection to their primitive past when even their dwellings were made with it. Hence, the earth is a vital element for humanity. Jung ${ }^{46}$ supports that «Nietzsche has expressed that very beautifully: you shall become friends of the immediate things. And the immediate things are this earth, this life». For Jung, this earth and the bond that exists between her and individuals is of foremost importance; moreover, he goes further in declaring that «[f]or quite a long time enough our ancestors, and ourselves, have been taught that this life is not the real thing, that it is provisional, and that we only live for Heaven... In the course of the centuries man has repeatedly experienced the fact that the life that is not lived here, or the life lived provisionally, is utterly unsatisfactory» ${ }^{47}$. In the book-length poem, Kinnell delves into these appreciations because in the completion of the quest, the hero is faced with the integration of the four basic elements that guides him to accept nature and its processes because «Living brings you to death, there is no other road» ${ }^{48}$. In fact, before the persona starts his physical journey, he

$$
\begin{aligned}
& \text { (...) sit[s] a moment } \\
& \text { by the fire, in the rain, speak } \\
& \text { a few words into its warmth- } \\
& \text { stone saint smooth stone - and sing } \\
& \text { one of the songs I used to croak } \\
& \text { for my daughter, in her nightmares }{ }^{49} \text {. }
\end{aligned}
$$

The persona «feels» the earth as he rests on it and besides that fact, he experiences a moment of unity among the four elements: there is rain that falls but that does not put out the fire and its flames; on the contrary, from them, warmth emanates. Moreover, as he witnesses this scene, he sings as his daughter when she was born; so, air inflates his lungs when he tries to communicate his message of the unity achieved. All these actions happen simultaneously while being rooted to earth.

Likewise, for discovering this verity, the hero, when starting his journey, finds that the bear, his animal-link to the discovering of his self, is «[s]omewhere out ahead of me», sitting

$$
\text { (...) alone }
$$

\footnotetext{
${ }^{46}$ Meredith Sabini, The Earth..., 86.

${ }^{47}$ Meredith Sabini, The Earth..., 86.

${ }^{48}$ Galway Kinnel, The Book of..., 73.

${ }^{49}$ Galway Kinnel, The Book of..., 4. 
on his hillside, nodding from side

to side. He sniffs

the blossom-smells, the rained earth,

finally he gets up,

eats a few flowers, trudges away ${ }^{50}$.

This strong creature is sitting on earth, on a protuberant section of the soil, so that he can be noticed by the hero; moreover, the bear moves from one side to the other, smelling the earth, the female principle being impregnated with another element, the water, and being able to smell both through the air. These actions are part of his preparatory involvement for the journey to come. As the hero moves forward in this first moment of the call, he is faced with a metaphor of earth representing the womb of a mother and the baby in it:

\author{
It is all over, \\ little one, the flipping \\ and overleaping, the watery \\ somersaulting alone in the oneness \\ under the hill, under \\ the old, lonely bellybutton \\ pushing forth again \\ in remembrance ${ }^{51}$.
}

Contrary to the bear, this baby is not on the hill but «under the hill», but alone like the bear and moving from one side to the other. The womb as the earth, in this case the hill, symbolizes a life-giving principle that will accompany the hero as he progresses in his quest.

Even when these references to the element earth are positive not all the ones present in the poem are so. Perhaps, he could not understand his connection to the elements alive and living. The persona seems to have faced difficult moments of grief and pain in company of and how through the comprehension of their principles, he could achieve more knowledge on the task of being his daughter for
When it was cold
on our hillside, and you cried
in the crib rocking
through the darkness, on wood

${ }^{50}$ Galway Kinnel, The Book of..., 4.

${ }^{51}$ Galway Kinnel, The Book of..., 5

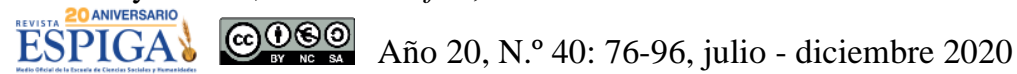


knifed down to the curve of the smile, a sadness

stranger than ours, all of it

flowing from the other world,

I used to come to you

and sit by you

and sing to you. You did not know,

and yet you will remember ${ }^{52}$.

Father and daughter developed an intimate connection that would last through time even when there were moments of struggle while alive on earth; however, even when these could have been harsh on them, they also felt protected as the baby was in a wooden crib that shielded her from darkness. And this encounter with a presence from «the other world», may have scared both: one for its ingenuity and the other for his lack of knowledge. Nevertheless, they possessed a connection: singing that brought, and will bring, comfort for both in moments of despair. However, indistinctively of a grieving moment, the earth will protect its inhabitants and inside her death will morph into life. This resolution of this binary opposition is declared at the end of the poem when the persona cries out loud:

\author{
This poem \\ if we shall call it that, \\ or concert of one \\ divided among himself, \\ this earthward gesture \\ of the sky-diver ${ }^{53}$.
}

This journey of self-discovery taken by the quester comes to an end when he comprehends that this passage was necessary for him to understand that life takes you to death but in death life is found. As Paz ${ }^{54}$ asserts, «[a]sí, frente a la muerte hay dos actitudes: una, hacia adelante, que la concibe como creación; otra, de regreso, que se expresa como fascinación ante la nada o como nostalgia del limbo ${ }^{55}$ (p. 198); for Kinnell, in The Book of Nightmares, the movement is foreward, as creation.

\footnotetext{
${ }^{52}$ Galway Kinnel, The Book of..., 7.

${ }^{53}$ Galway Kinnel, The Book of..., 75.

${ }^{54}$ Octavio Paz, El Laberinto..., 198.

55 Thus, when facing death there are two attitudes: one forward, that envisages it as creation; another, backwards, that is expressed as a fascination in the face of the abyss or nostalgia of limbo» (my translation).
}

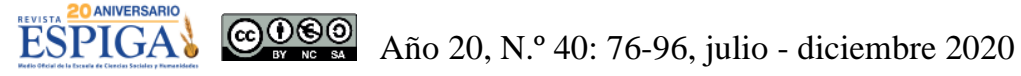




\section{Conclusions}

As the world is populated by many kinds of people in dissimilar places, one way to attempt to understand humanity is through a comparative method that can be utilized to reach a possible understanding of myth and its particulars. Consequently, it is through a comparison exercise of certain repetitive patterns in different cultures, separated by time and distance coordinates, that recurring models are discovered. Jung defined these patterns as «archetypes», which etymologically come from «arche» that means primordial and «typos» that means typical. These archetypical images will circumscribe to the most primordial elements of human existence and experience; they manifest in people as influential and vigorous images that have repeated through time, from thousands of years ago to today.

Therefore, the symbolic elements of cultures around the world can be very alike because they materialized from the archetypes that are shared by humankind. Consequently, the primeval past, shared by all, developed into the foundation of the psyche prompting individuals to act in accordance to not only what humanity considers characteristic of a specific time and place but to some knowledge of a disremembered past that echoes in the present. These patterns are displayed in Kinnell's poetry that definitely belongs to the natural world. In The Book of Nightmares, starting in section I, the persona encounters natural imagery in general and the four classical elements: water, fire, wind and the earth, in particular. Certainly, his poetry is concrete and looks for an organic answer from the reader because for him being alive on earth involves sharing life with nature and its creatures.

Moreover, it seems that the natural world and the basic instinctual drives of humankind mean to be one with the self and with nature. «Earthly» experiences and objects become the poet's source of inspiration. Nelson ${ }^{56}$ asserts that «very few contemporary poets care or dare or are able to communicate the peculiar pleasure of words on the tongue as vividly as Kinnell» (Introduction). Kinnell's poetry began as relatively formal and structurally intricate texts, but he moved to a simpler diction and to an overall freer structure. Diction and structure in his poems mirror life as a simple moment of transcendence into the universe, and as the writer himself has declared, poetry, in general, pursues wholeness when the person in the poem is any person and as the poem develops, this individual morphs into an animal and this creature keeps on morphing until it becomes a stone and if the stone could utter a word, that would be its language: becoming part of the whole.

The Book of Nightmares has been provided with a remarkable use of natural imagery that facilitates the understanding of the life-death binary opposition. These two apparently contradictory realms, life and death, are challenging to understand as elements of a unity, since for many individuals, especially in Western society, have been taught to appreciate life and disregard death as a real and vital component of this duality. Nevertheless, in this book-length poem, Kinnell succeeds in revealing their ancestral relationship through natural imagery; hence, the persona makes use of imagery like the rain, the stones of the path, as well as the other classical elements to craft a poetic world to which individuals can relate.

\footnotetext{
${ }^{56}$ Howard Nelson, On the Poetry..., 6. 
Formato de citación según APA

Quirós-García, E. (2020). Classical Elements of Nature in Galway Kinnell's The Book of Nightmares. Revista Espiga, 20 (40), páginas 76-96

\section{Formato de citación según Chicago-Deusto}

Quirós-García, Elizabeth. «Classical Elements of Nature in Galway Kinnell's The Book of Nightmares». Revista Espiga 20, n. ${ }^{\circ} 40$ (julio-diciembre, 2020): páginas $76-96$

\section{Works cited}

Achtemeier, Paul J. ed. The HarperCollins Bible Dictionary. New York: HarperCollins Publishers, 1985.

Barthes, Roland. Mythologies. New York: Hill and Wang, 1999.

Biedermann, Hans. Dictionary of symbolism. Translated by James. Hulbert. New York: Facts on File. (Original work published in 1989), 1992.

Bloom, Harold., ed. Contemporary Poets. New York: Infobase Publishing, 2010.

Calhoun, Richard. Galway Kinnell. New York: Twayne Publishers, 1992.

Campbell, Joseph. Myths to Live by. New York: The Viking Press, 1972.

--- The Power of Myth. New York: Anchor Books, 1991.

--- Pathways to Bliss. California: New World Library, 2004a.

--- The Hero with a Thousand Faces. Boston: Princeton University Press, 2004b. 
Cirlot, Juan E. A Dictionary of Symbols. Translated by Jack Sage. London: Routledge, 1962.

Ferber, Michael. A Dictionary of Literary Symbols. Cambridge: Cambridge University Press, 1999.

Howard, Richard. Alone with America: Essays on the art of poetry in the United States. New York: Atheneum, 1980.

Jung. Carl G. Symbols of Transformation. London: Routledge \& Kegan Paul, 1956.

--- The Archetypes and the Collective Unconscious. London: Routledge \& Kegan Paul, 1959.

--- Man and his Symbols. New York: Dell Publishing Co., Inc, 1964.

--- Memories, Dreams, Reflections. New York: Pantheon, 1961.

--- Four archetypes. Boston: Princeton University Press, 1970

--- The Undiscovered Self. New York: A Signet Book, 2006.

--- Modern Man in Search of a Soul. New York: Hartcourt, Inc, 2010.

Kinnell, Galway. The Book of Nightmares. Boston: Houghton Mifflin Company 1971a.

--- Walking down the stairs: Selections from interviews. Michigan: The University of Michigan Press, 1978.

Mikics, David. A New Handbook of Literary Terms. Boston: Thomson Shore Inc, 2007.

Mills, Ralph .J., Jr. «A reading of Galway Kinnell». The Iowa Review, 1(1),(1970a) 66-86. Retrieved from http://www.jstor.org/stable/20157537

--- «A reading of Galway Kinnell: Part 2 (Continued)». The Iowa Review, (1970b) 1(2), 102-122. Retrieved from http://www.jstor.org/stable/20157579

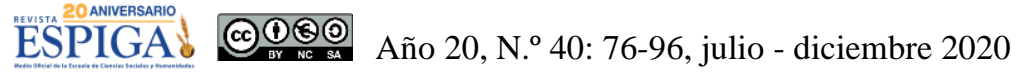


--- Cry of the human essays on contemporary American poetry. Chicago: University of Illinois Press, 1975.

Nandi, Rinku. «Archetypal approach to Eliot's "The Wasteland"». An Interdisciplinary Journal of Literary Studies 1, $\mathrm{n}^{\circ} 1$ (2016): 57-66. Retrieved from http://postscriptum.co.in/wpcontent/uploads/2016/09/RINKU-NANDI.pdf

Nelson, Howard. On the Poetry of Galway Kinnell. Michigan: The University of Michigan Press. 1987.

Paz, Octavio El Laberinto de la Soledad. Madrid: Ediciones Cátedra, 1995.

Sabini, Meredith., ed.C.G. The Earth has a Soul: Jung on Nature, Technology \& Modern Life. (1st ed). California: North Atlantic Books, 2001.

Samuels, Andrew. Jung and the Post-Jungians. London and New York: Routledge \& Kegan Paul, 1985.

Sugg, Richard, ed. Jungian Literary Criticism. Evanston, Illinois: Northwestern University Press, 1992.

Taha, Aseel Abdul Lateef. «The Allegorical Use of the Rituals of Hunting in Galway Kinnell's “The Bear"», Journal of the College of Languages, $\mathrm{n}^{\circ} 28$ (2018): 51-65. Retrieved from http://www.iasj.net/iasj?func=fulltext\&aId=81622

The Poetry of Galway Kinnell. Literary Cavalcade, 2000, vol. 53, no. 1, 16-18. Retrieved from http://search.proquest.com/docview/210471429?accountid=32236

Zimmerman, Lee. The poetry of Galway Kinnell. Chicago: University of Illinois Press, 1987. 